\title{
Zakiah Daradjat's Mental Hygiene and its Relevance to face The Problems of Contemporary Adolescence in Indonesia
}

\author{
Muhmmad Nurrosyid Huda Setiawan ${ }^{1}$, Asep Awaludin², Abdullah Muslich Rizal Maulana ${ }^{3}$ \\ Universitas Darussalam Gontor Ponorogo, Jl. Raya Siman, Ponorogo, East Java ${ }^{1,2,3}$ \\ \{nurrosyidhudasetiawan@unida.gontor.ac.id ${ }^{1}$,asep@unida.gontor.ac.id ${ }^{2}$,amrizalm@unida.gontor.ac.id ${ }^{3}$ \}
}

\begin{abstract}
Zakiah Daradjat is a Religious Psychologist who reformulated the concept of 'Mental Hygiene' to treat Indonesian adolescent problems. Accordingly, religious values that were not included in the previous version of the concept are the most crucial point. Main idea of this concept is Avicenna's concept of the relation between body and the soul, which becomes the principle of mental hygiene. This research utilizes religious psychology approach and a grounded research method to elaborate issues related to nowaday Indonesian adolescents; confirming the relevance of Daradjat's mental hygiene concept challenging such problems. This research indicated: First, the concept of mental hygiene is still significant to be applied in Daradjat's educational institution: Ruhama; second, the provisional results displayed positive response of the adolescents who were the samples in this study; while the preliminary results of the analysis of the mapping of adolescent problems, may be answered with the concept of Daradjat's mental hygiene.
\end{abstract}

Keywords: Zakiah Dardjat; Mental Hygiene; Problems of Contemporary Adolescence

\section{Introduction}

The discussion on mental hygiene has been widely discussed by psychologists, including one of the Muslim psychologists, Zakiah Daradjat. Although mental hygiene is a part of psychology that has been around for a long time, Zakiah Daradjat was able to reformulate it then became a distinctive concept. By emphasizing a religious basis, a healthy mentality will be well-formed. The topic is crucial to discuss because the authors will find a concrete relevance of this concept to answer the problems of current adolescents' lives in Indonesia.

\section{Discussion}

\subsection{The Origin of Zakiah Daradjat's Mental Hygiene}

Mental Hygiene or health science is the study of mental especially focusing on mental health problems. It intended to prevent emotional disorders as well as advancing people's 
mental health. Etymologically, mental hygiene comes from the words: mental and hygiea. Mental was derived from the Latin word mens / mentis which means soul; Meanwhile, hygiea is the name of the Greek goddess of health; which later developed as a 'health science'. Sometimes, Mental Hygiene is also called 'Psycho-Hygiene' [1].

Historically, mental hygiene can be drawn from the history of the development of abnormal psychology and psychiatry in the United States of America in 1783. It was a doctor, Benjamin Rush (1745-1813) who was assigned to treat 24 patients who were considered lunatics. Rush, unlike the irrational method practiced by previous ages, treated his patients using a rational way. His method includes and encouragement and motivation so that affected the birth of mental hygiene [2]. Funkhouser once affirmed that mental hygiene should be in balance way with physical hygiene in order to maintain the proper condition of mankind.[3] As such, mental hygiene plays its role to comprehend human mental issues and attempted to find the most applicable solution [4]-[7], [7] [8].

The concept of mental hygiene Zakiah Daradjat is a work of reformulation of the existing concept of mental hygiene itself. This is marked by the biographical history of Zakiah Daradjat who studied the concept of mental hygiene in Egypt in 1950. The reformulation process is very clear with the special characteristics inherent in the mental hygiene concept of Zakiah Daradjat. This particular characteristic is the emphasis on religious knowledge and its relationship in building one's mental health [9]. She said that religion is a basic need that is needed by the soul of every human being[10]. As such, to be religious in the context of psychology is owning both religious consciousness and experience altogether [11].

\subsection{The Influence of Ibn Sina's Thought towards Zakiah Daradjat}

This research affirmed as well that the reformulation process of the concept of mental hygiene by Darajat was intellectually influenced by one of the classic Muslim scholars named Ibn Sina/ Avicenna (980-1037 AD). The concept of Darajat's mental hygiene consists of religious essences; confirming that to sustain their emotional affair, the human should look after not only their physical needs but also spiritual. Such a formula was comprehensively constructed by Avicenna with his dualism theory in which he affirmed that human consists of two-dimensional aspects: material and immaterial. According to Avicenna, the immaterial dimension of humans i.e the soul is the essence of humans.[12] Hence, the body is fully dependent on the soul. Contextually, the wellness of the physical dimension is strongly affected by the state of this soul. [13].

Further, in Canon of Medicine, Avicenna which is his Magnum Opus, used to be one of the main medical references in the east and the west for more than six centuries [14], Avicenna used the term "melancholia" and "sadness" as those were understood as depression. Thus, his methods of curing such cases have great deals on mental hygiene. This polymath even used aromatherapy, music therapy, and the Quranic recitation for the treatments of most diseases [15]. Thus in this context, it surely can be understood that Zakiah Daradjat in her concept of mental hygiene was indirectly yet heavily influenced by Avicenna since her reformulated mental hygiene concept was is accordance with the concept of that one of Avicenna's.

\subsection{The Problems of Contemporary Adolescence in Indonesia}

According to Experts, adolescence is a distinguished phase of life cycle between infancy and adulthood. [16] During this time, children are able to navigate any changes to realize their 
potential as well as find risks and vulnerabilities.[17] Currently, adolescences are now often referred to as the millennial generation; born in the ratio between 1980 and 2000 and often defined as generation ' $\mathrm{Y}$ ' $[18]$

Adolescents, indeed face a lot of challenges; ranged from climate changes and the environment, poverty, unemployment, crime, etc; [17] while mental health is considered as one of the most alarming issues for them. [17], [19] As in Indonesia, adolescents are confronted with emotional symptoms, especially anxiety problems [20]. In order to solve these issues, a support system is essential to maintain their mental health. [21] Moreover, effective access to public health is also needed. [22]

The researcher uses a statistical data in mapping the problems of contemporary adolescents in Indonesia. First, the researcher distributed questionnaires to be answered by the sample communities; and second, analyzing the answers of the questionnaires. The authors used a sample of adolescents from various regions in Indonesia aged 14-20 years old boys and girls. The total sample was 202 children. The questionnaire used is the same questionnaire used by Zakiah Daradjat in his thesis in Egypt with some modifications. The points of his statement referred to Zakiah Daradjat's explanation in her previous questionnaire, namely 12 personal problems. The Problems are: Here is the list of Problems: The Problems of School, The Problems of Family, The Problems of Health, Problems in Choosing a Job and Study Ability, Problems of Personal and Social Growth, Emotional Problems, The Problems of Leisure Time, The Problems of Sex, The Problems of Financial, The Problems of Family Preparation, The Problems of Social Life, The Problems of Religion and Attitude.[23]

After processing data, we can find that the issues of nowadays adolescences were not truly different from what has been experienced in the 60-70s generations. The most striking point is that contemporary adolescences are in very close relationships with gadgets, dissimilar with elders who did not arrive in such massive electronic discovery dealt with current adolescences. Moreover, the author also found that there has been a shift in the tendency for problems of early adolescence and late adolescence.

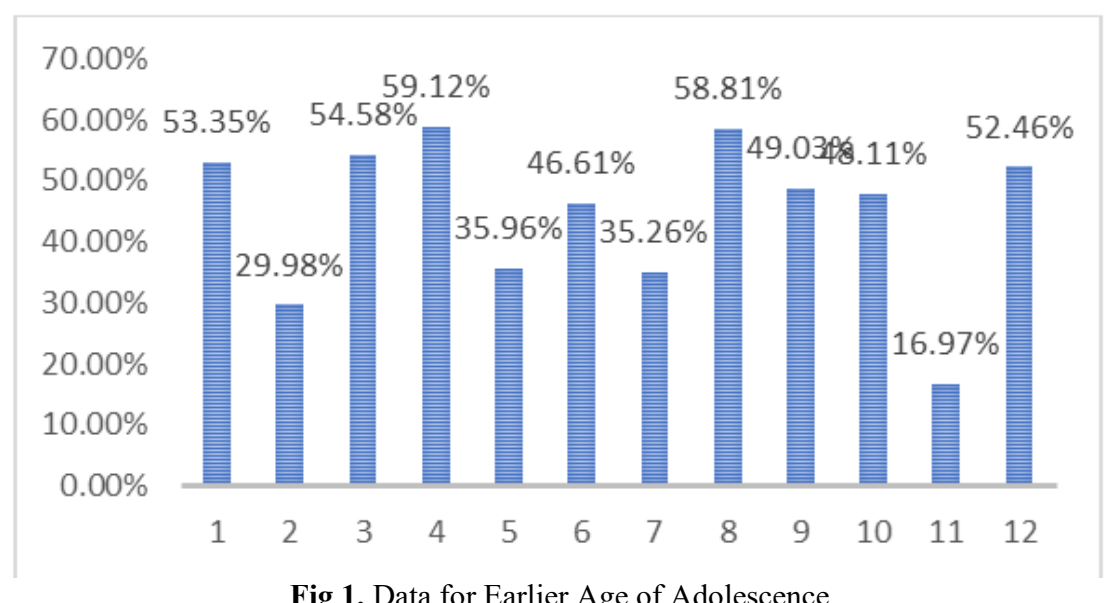

Fig 1. Data for Earlier Age of Adolescence

From the above data, it is obvious that the highest percentage of problems faced by adolescence at the earlier age is 'The Problems of Choosing a Job and Study Ability' as the number reached $59,12 \%$ of respondents while 'The Problems of Social Life' is considered as the most uncompromised issue arrive only at $16,97 \%$ from them. 


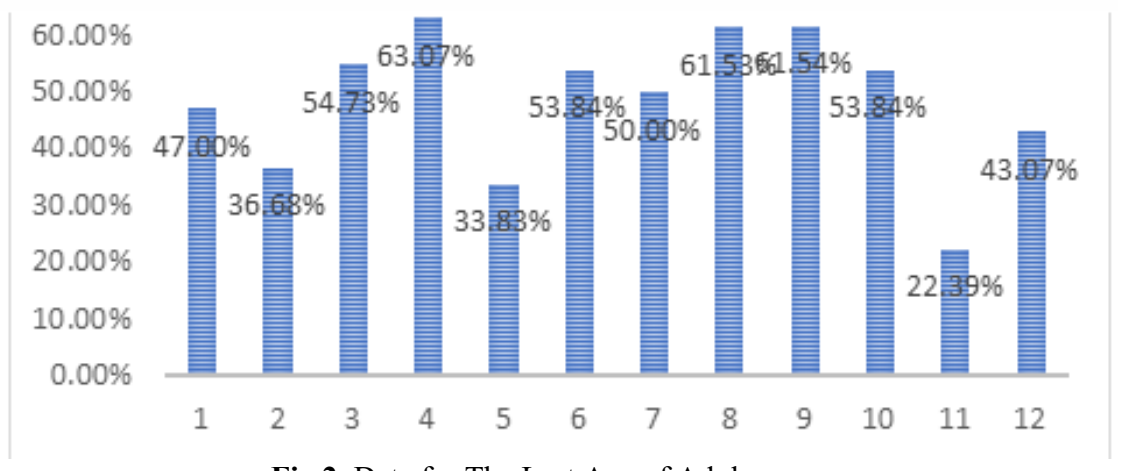

Fig 2. Data for The Last Age of Adolescence

On the other side, the last age of adolescence considered ' The Problems of Choosing a Job and Study Ability' as the most threatening issue for them; as 63,07\% of the samples confirmed it. Meantime, they recognized 'The Problems of Social Life' inconsequentially as the problem is barely reported by $22,39 \%$ of adolescents.

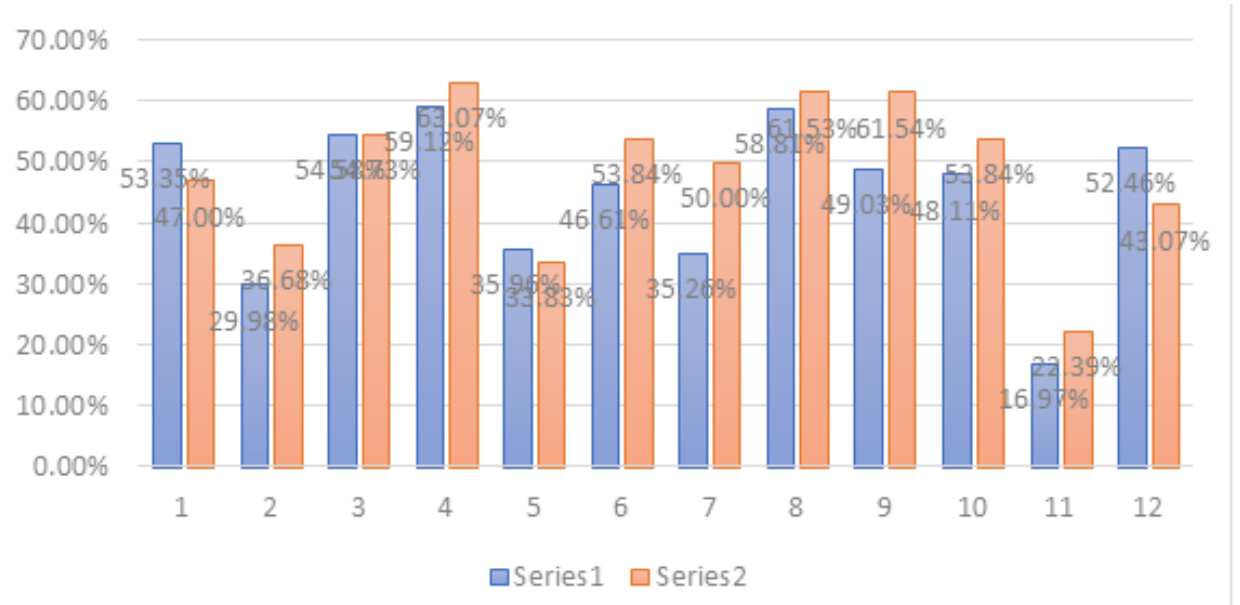

Fig 3. The Trend of increasing and decreasing percentage of adolescents problems

The third diagram proved diverse changes in every trend. Each issue fluctuated, but the 'The Problem of Leisure Team' rose steeply by $14,74 \%$. 'The Problem of Religion and Attitude', however. On the other side, 'The Problem of Religion' sunk dramatically from $52,46 \%$ to $43,07 \%$; accomplishing a $9,39 \%$ drop.

\subsection{The Relevance of Mental Hygiene Concepts in Facing Contemporary Adolescent Problems in Indonesia}

This research confirms significant relevances of Darajat's mental hygiene in resolving issues of current Indonesian adolescents they are: First, Islamic Foundation Ruhama -a school founded by Darajat- applied Darajat's mental hygiene; Second, there are positive responses from adolescents receiving the concept of Darajat's mental hygiene and; Third, Researcher 
believes in a strong hypothesis regarding problems of nowadays Indonesian adolescents can be faced with the concept of Daradjat's mental hygiene.

To conclude, there are 5 major findings regarding those relevances: First, in Ruhama, Teachers are required not only to share materials but to introduce learning spirit as well; Second, the student counseling and development are applied to both students with problems and prestigious ones; Third; the second point is done altogether with the sharing session with student's parents and/or guardians; Fourth, exploring student roles and the problems they engaged in the society and; Fifth, enlivening the teaching of Arabic and Quranic memorizing to purify student's soul.[24] Ruhama, In accordance with Darajat's mental hygiene, developed a motto for their educational institution: "My School is my paradise" (Sekolahku Surgaku) [25].

In relation to Darajat's conception of mental hygiene, there are ' 4 layers of the soul' constructing the mental situation of current Indonesian adolescents: Sensing, Reasoning, Empathy, and Spiritual.[26] The major cause of their psychological issues is that recent adolescents in Indonesia barely occupies the 'Sensing' layer. This spot is considered exposed to problems; as they only acknowledge their surrounding condition based on their sensual experience. The adolescents who relied on their 'Spiritual' layer, quite the opposite; they admit religious knowledge as a primary source of truth preceded the sensual preferences. Thereupon, adolescents who hold the 'Spiritual' layer will gain a better cerebral treatment then finally ended with a healthier condition of the soul.[27]

\section{Closing}

After conducting the research, the authors concluded that the concept of Daradjat's mental hygiene is still relevant to answer the problems of contemporary adolescents in Indonesia. However, it is necessary to develop this concept by digitalizing the councealing method in accordance to this contemporary adolescents. The main point in this concept shows that religiousity as the core of reformulated Darajat's mental hygiene.

\section{Acknowledgements}

As a part of Junior Lecturer Research (Penelitian Dosen Pemula), this project was funded by the Directorate of Research And Community Service, Directorate General of Research Advancement and Development, The Ministry of Research, Technology, and Higher Education (KEMENRISTEKDIKTI); now it is under The Ministry of Education and Culture (KEMENDIKBUD)) The Republic of Indonesia.

\section{References}

[1] K. Kartono and J. Andari, Hygiene Mental dan Kesehatan Mental dalam Islam. Bandung: CV Mandar Maju, 1989.

[2] Y. Syamsu, Mental Hygiene Perkembangan Kesehatan Mental dalam Kajian Psikologi dan Agama. Bandung: Pustaka Banu Quraisy, 2004. 
[3] W. L. Funkhouser, "Mental Hygiene," The Journal of Nervous and Mental Disease, vol. 55, no. 5, 1922, [Online]. Available: https://journals.lww.com/jonmd/Fulltext/1922/05000/Mental_Hygiene.45.aspx.

[4] A. Cunha, O. Junior, and L. Silva, "THE PERFORMANCE OF THE SOCIAL VISITING NURSE AS A MONITOR OF MENTAL HYGIENE (1927-1942)," $R$. pesq.: cuid. fundam. Online, vol. 5, no. 3, pp. 318-327, Jul. 2013, doi: 10.9789/21755361.2013v5n3p318.

[5] V. S. De Aguiar Júnior, A. M. De Oliveira, and L. C. A. De Araújo, "Hygiene and mental health: body care in the clinical intervention in a CAPSI," $R$. pesq. cuid. fundam. online, vol. 7, no. 2, p. 2582, Apr. 2015, doi: 10.9789/21755361.2015.v7i2.2582-2590.

[6] J. Im, "A Study of the Discussions on Psychiatry of Korea in the 1960s and 1970s* From Mental Hygiene to Modern Psychiatry -," Korean J Med Hist, vol. 26, no. 2, pp. 181-214, Aug. 2017, doi: 10.13081/kjmh.2017.26.181.

[7] J. Jovic, M. Knezevic, D. Ilic, M. Ristic, M. Krstic-Ristic, and D. Ignjatovic-Ristic, "Elements of mental hygiene and diet as factor of control chronical renal disease," Praxis Med, vol. 45, no. 2, pp. 65-71, 2016, doi: 10.5937/pramed1602065J.

[8] J. R. Ewalt, "Mental Hygiene in Public Health," The American Journal of Tropical Medicine and Hygiene, vol. 5, no. 2. The American Society of Tropical Medicine and Hygiene, pp. 346-347, 1956, doi: https://doi.org/10.4269/ajtmh.1956.5.346.

[9] Z. Daradjat, Kesehatan Mental. Jakarta: PT Gunung Agung, 1985.

[10] Z. Daradjat, Pendidikan Agama Dalam Pembinaan Mental. Jakarta: Penerbit Bulan Bintang, 1982.

[11] Z. Daradjat, Ilmu Jiwa Agama. Jakarta: Penerbit Bulan Bintang, 1976.

[12] M. U. Najjati, al-Dirasat al-Nafsaniyah 'inda al-'Ulama al-Muslimin. Cairo: Dar alSyuruq, 1993.

[13] F. Khalif, Ibnu Sina wa Madzhabuhu fì an-Nafs. Beirut: Jami’ah Beirut al-'Arabiyah, 1974.

[14] S. NG, Avicenna in Renaissance Italy: The 'Canon' and the Medical Teaching in Italian Universities after 1500. Princeton, N.J: Princeton University Press, 1987.

[15] M. A. Khodaei et al., "Avicenna (980-1032CE): The Pioneer in Treatment of Depression," Transylvanian Review, p. 14, 2017.

[16] L. M. Richter, "Studying Adolescence," Science, vol. 312, no. 5782, pp. 1902-1905, Jun. 2006, doi: 10.1126/science.1127489.

[17] UNICEF, Ed., Adolescence: an age of opportunity. New York, NY: UNICEF, 2011.

[18] Kementerian Pemberdayaan Perempuan dan Perlindungan Anak dan Badan Pusat Statistik, "Statistik Gender Tematik: Profil Generasi Milenial Indonesia.," Kementerian Pemberdayaan Perempuan dan Perlindungan Anak, 2018.

[19] World Health Organization and N. Department of Maternal Child and Adolescent Health, Updated guideline. care of critically-Ill children. 2016.

[20] S. S. Turnip, "TIME PERSPECTIVE AND PSYCHOLOGICAL PROBLEMS AMONG ADOLESCENTS AFFECTED BY VIOLENT CONFLICT IN INDONESIA," Makara Hubs-Asia, vol. 14, no. 2, p. 98, Dec. 2010, doi: 10.7454/mssh.v14i2.673.

[21] N. M. D. Sulistiowati, B. A. Keliat, I. Y. Wardani, S. F. S. Aldam, R. Triana, and M. V. A. Florensa, "Comprehending Mental Health in Indonesian's Adolescents through Mental, Emotional, and Social Well-Being," Comprehensive Child and Adolescent 
Nursing, vol. 42, no. sup1, pp. 277-283, Mar. 2019, doi: 10.1080/24694193.2019.1594460.

[22] D. Ayuningtyas, M. Misnaniarti, and M. Rayhani, "ANALISIS SITUASI KESEHATAN MENTAL PADA MASYARAKAT DI INDONESIA DAN STRATEGI PENANGGULANGANNYA," JIKM, vol. 9, no. 1, Oct. 2018, doi: 10.26553/jikm.2018.9.1.1-10.

[23] Z. Daradjat, Problema Remaja di Indonesia. Jakarta: Penerbit Bulan Bintang, 1974.

[24] Ridwan, "focus group discussion," Aug. 27, 2020.

[25] Juhdi, "focus group discussion," Aug. 06, 2020.

[26] B. Riyono, "Sensing Mentality and the Cognitive-Spiritual Intervention," Minbar. Islamskie issledovaniâ, vol. 12, no. 4, pp. 1091-1106, Jan. 2020, doi: 10.31162/26189569-2019-12-4-1091-1106.

[27] B. Riyono, “focus group discussion," Sep. 26, 2020. 